\title{
DEE/PC/95256--TI \\ Investigation and Demonstration of \\ Dry Carbon-Based Sorbent Injection for Mercury Control
}

\section{Contract DE-AC22-95PC95256}

Quarterly Technical Report

November 1 - December 31, 1995

February 5, 1996

Public Service Company of Colorado: Terry Hunt

ADA Technologies: Sharon Sjostrom

DOE Program Manager: Tom Brown

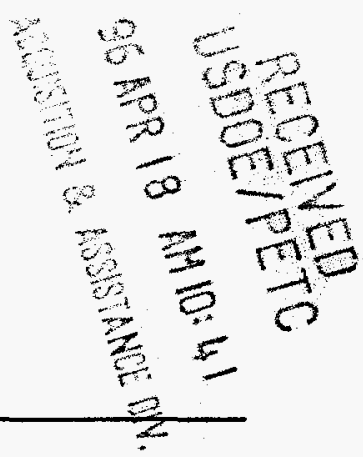

Executive Summary

The overall objective this two phase program is to investigate dry carbon-based sorbents for mercury control. This information is important to the utility industry in anticipation of pending regulations. During Phase I, a bench-scale field test device that can simulate an electrostatic precipitator, a pulse-jet baghouse, or a reverse-gas baghouse will be designed and integrated with an existing pilot-scale facility at Public Service Company of Colorado's (PSCo's) Comanche Station. Various sorbents will then be injected to determine the mercury removal efficiency for each. During the Phase II effort, component integration of the most promising technologies (technically and economically feasible) shall be tested at the $5000 \mathrm{acfm}$ pilot-scale.

An extensive work plan has been developed for the project. A maximum of 4 sorbents will be selected through investigation, presentation, and discussion among team members: PSCO, Electric Power Research Institute (EPRI), ADA Technologies (ADA), and the U.S. Department of Energy (DOE). The sorbents will be tested in the five primary bench-scale configurations: pulse-jet baghouse, TOXICON, reverse-gas baghouse, electrostatic precipitator, and particulate control device with no ash. In the EPRI TOXICON system, mercury sorbents are injected downstream of a primary particulate control device, and collected in an pulse-jet baghouse operated at air-to-cloth ratios of 12 to $16 \mathrm{ft} / \mathrm{min}$, thus separating the mercury and sorbent from the captured flyash. In the no-ash configuration, an external flyash sample will be injected into a clean gas stream to evaluate the ability of different ashes to remove mercury. The use of an 


\section{DISCLAIMER}

This report was prepared as an account of work sponsored by an agency of the United States Government. Neither the United States Government nor any agency thereof, nor any of their employees, makes any warranty, express or implied, or assumes any legal liability or responsibility for the accuracy, completeness, or usefulness of any information, apparatus, product, or process disclosed, or represents that its use would not infringe privately owned rights. Reference herein to any specific commercial product, process, or service by trade name, trademark, manufacturer, or otherwise does not necessarily constitute or imply its endorsement, recommendation, or favoring by the United States Government or any agency thereof. The views and opinions of authors expressed herein do not necessarily state or reflect those of the United States Government or any agency thereof. 
existing test facility, a versatile design for the test fixture, and installation of a continuous mercury analyzer will allow for the completion of this ambitious test plan.

The final sorbent selection, originally scheduled to be completed in January 1996, has been postponed until late April. Mercury sorbent evaluations are being conducted at various EPRI and DOE laboratories under separate programs. The results of these evaluations will be reviewed in April to finalize the list of sorbents to be tested in this Phase I effort. It is expected that FGD activated carbon will be one of the sorbents tested due to the availability of test data and encouraging results. This delayed task does not affect the overall project schedule.

The primary task currently underway is the facility design. The design is expected to be finished in January, 1996. The facility, regardless of the particulate control module configuration, will be fitted with supply line injection ports, through which mercury sorbents and $\mathrm{SO}_{2}$ control sorbents can be added to the flue gas stream. Several sorbent injection ports are included in the design to vary the in-duct residence time from 0.75 to 1.5 seconds. An in-duct heater will be installed to vary and control flue gas temperature. In-duct spray cooling for temperature reduction will be accomplished through the test ports. A heat exchanger can also be used to cool the gas without adding moisture. The particulate control module has a hopper on the bottom for storing the collected fly ash and sorbent products; the hopper design will accommodate returning the collected products to the flue gas stream, retaining them for separate disposal, or recycling them to increase the utilization rate.

\section{Activities During Reporting Period}

\section{Task 1. Sorbent Selection}

The objective of this task is to identify and select the most promising sorbents to be tested. The team of PSCO, ADA, and EPRI in consultation with DOE shall provide input and recommendations as to the sorbents that are showing the most promise from on-going research programs. Results from testing in EPRI laboratories should be available by April 1996. Based on this schedule, the final selection of sorbents has been postponed until late April.

To evaluate the ability of flyash to adsorb mercury from flue gas, an Eastern and Midwestern ash will be selected based on results from EPRI and DOE laboratory tests. Samples 
of PSCo's Comanche and Arapahoe Generating Station flyash will be included in the laboratory evaluations. Other ash candidates include an ash from an Eastern low sulfur coal with high unburned carbon measured using Loss On Ignition (LOI) due to low $\mathrm{NO}_{x}$ burners. Arapahoe Station also has low NO $\mathrm{x}_{\mathrm{x}}$ burners and has relatively high unburned carbon in the flyash due to its unique firing method. Previous mercury testing at Arapahoe has shown approximately $\mathbf{7 5 \%}$ mercury removal. Other flyash candidates are being discussed.

A new sorbent selection matrix was developed based on a conference call between PSCo, DOE, EPRI and ADA. This proposed matrix is included in appendix $A$. The final matrix will not be finalized until early May, 1996.

\section{Task 2. Design of bench-scale pilot}

The initial design of the bench-scale pilot is expected to be finished by the end of January, 1996. Drawings of the facility will be submitted to PSCo engineers for approval. Vendor bids for materials will be included with the drawings. An overall arrangement schematic is presented in Figure 1. The existing ductwork and fan are shown in dashed lines in the sketch. The bench-scale facility is indicated by solid lines and includes details such as the duct heater, injection ports, flow sensors, and dampers.

Final approval of the design by PSCo and release to purchase equipment is expected by the middle of February, which will also mark the beginning of the fabrication stage. It is anticipated that the bench-scale facility will be installation at Comanche Station in May, 1996.

\section{Task 3. Field Evaluations of Sorbents for Mercury Control}

Actual testing at Comanche Station is not scheduled to begin until June, 1996. However, a preliminary one to two week data gathering visit to the plant is currently being discussed. This trip would include measuring baseline mercury concentrations in the Comanche pilot facility slipstream. Measurements would be made on gas drawn from both upstream and downstream of the existing full-scale reverse gas baghouse. Although this activity was not planned in the original test program, it is believed that the data will provide valuable information for test planning. The information collected would include data to quantify the variability with time of the baseline mercury concentration in Comanche's flue gas and any unexpected issues associated with 

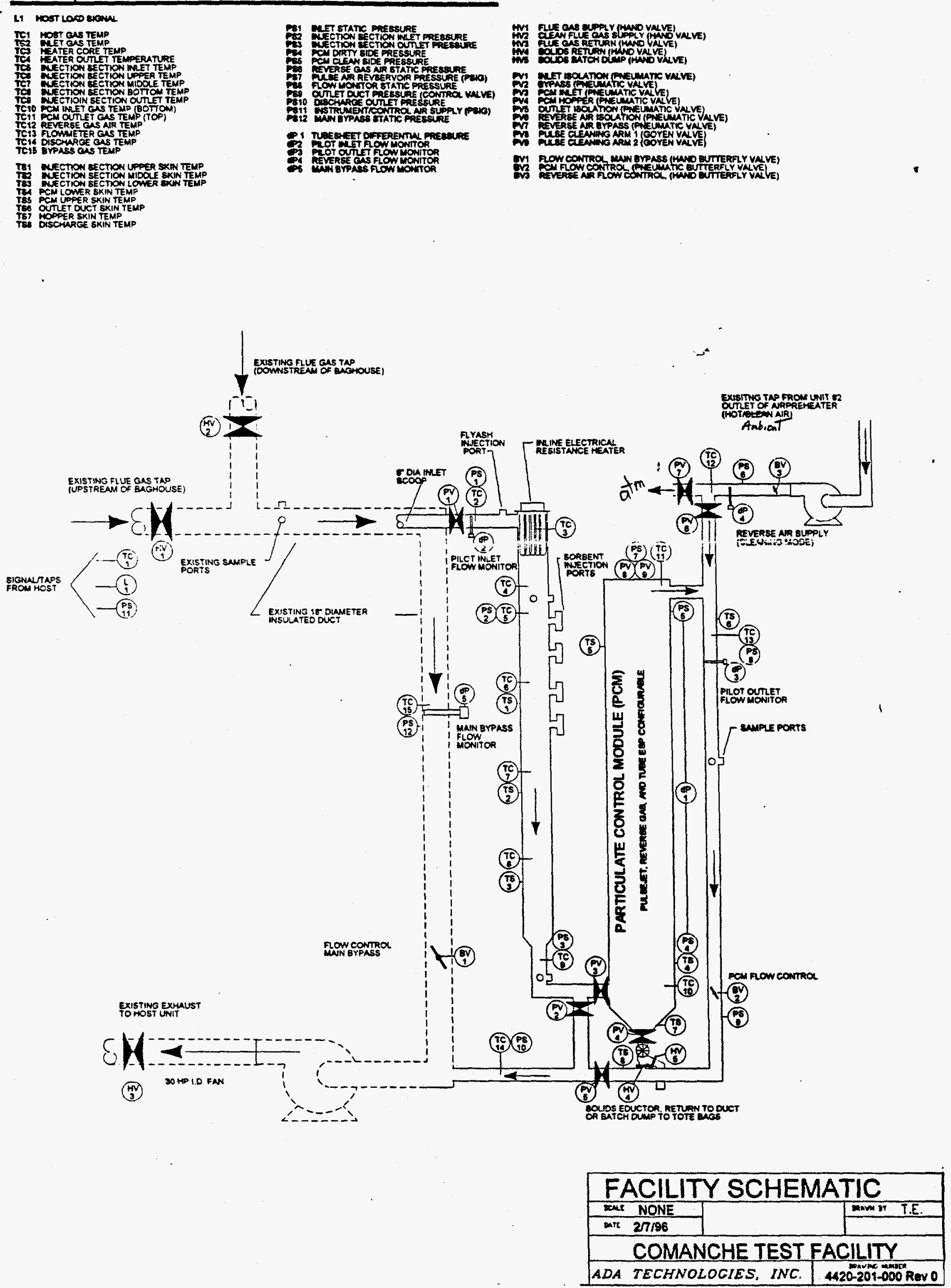
sampling. The baseline mercury measurements would be compared to previous mercury samples taken at the Comanche pilot facility.

The testing sequence is also currently being reviewed. During a conference call between PSCo, DOE, EPRI and ADA in December 1995, Ramsay Chang of EPRI suggested testing in an order of increasing total residence time. With the revised testing sequence, the ESP configuration would be tested first. In an ESP, there is little opportunity for the carbon sorbent, once collected on the plates, to continue removing mercury. In a fabric filter, flue gas continually passes through the dustcake of collected particulate matter. This represents additional opportunity for the carbon to adsorb mercury. In addition, the time the sorbent remains on the filter (time between cleans) is typically shorter in a pulse-jet than a reverse-gas baghouse. Therefore, the pulse-jet configuration would be tested second. The reverse-gas would be the final test configuration. This change in testing sequence has not been finalized and would not affect the projected start date or duration of testing.

\section{Task 6. Management and Reporting}

The Management Plan was presented to DOE during a project kickoff meeting at PETC on November 13, 1995. The Final Management Plan was reissued during December to incorporate comments from DOE.

The contract with ADA is being negotiated. It is expected that the contract will be reviewed and approved in January, 1996. The EPRI contract is also being reviewed.

\section{Activities Scheduled for Next Quarter (January 1 - March 31, 1996)}

\section{Task 1. Sorbent Selection}

Laboratory evaluations of potential sorbents and flyash candidates will continue. This work is being conducted at ADA and other labs on separate DOE and EPRI programs, however, the results from these evaluations will for the basis for sorbent and flyash selection in this Phase $I$. PSCo and ADA are assisting EPRI in identifying and collecting candidate flyash samples. 


\section{Task 2. Design and Fabrication of bench-scale pilot}

It is expected that the bench-scale design will be completed, approved and fabrication will be at least $50 \%$ complete by the end of next quarter.

\section{Task 3. Field Evaluations of Sorbents for Mercury Control}

Arrangements are being made for a data gathering visit to the host site during March or April 1996. This site visit is tentative due to demand for the continuous mercury analyzer on several DOE and EPRI programs.

Task 6. Management and Reporting

Contracts with $\mathrm{ADA}$ and EPRI are expected to be in place during the next quarter.

\section{Contract Concerns}

There are no concerns at this time. 


\section{ADA Technologies, Inc.}

\section{February 6, 1996}

TO: Terry Hunt

CC: Tom Brown, Ramsay Chang, Mike Durham, Jean Bustard

FROM: Sharon Sjostrom

RE: Dry Sorbent Evaluation: Revised Test Matrix

This is a proposed test matrix incorporates those items identified during our December 11, 1995 conference call. It is expected that each test condition will require 1 to 3 days of testing. The process conditions, flyash and sorbent characteristics to be evaluated include:

1. Duct temperature ranges
A) $190-210^{\circ} \mathrm{F}$ (expected cold weather baseline)
B) $225-275^{\circ} \mathrm{F}$ (expected warm weather baseline)
C) $300-325^{\circ} \mathrm{F}$

2. Duct residence time
A) 1 second
B) Design allows for 0.75 to 1.5 seconds

3. Mercury concentrations

Baseline (nominally $7 \mu \mathrm{g} / \mathrm{m}^{3}$ expected)

Doped (TBD based on site characterization test and issues with doping)

4. Methods to lower temperature

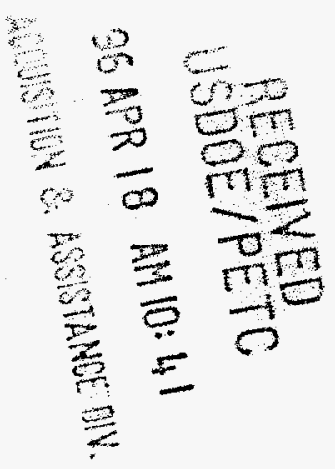

Cooling with water (increased moisture content)

Cooling with heat exchanger

5. Carbon particle size
5-7 $\mu \mathrm{m}$
$20-40 \mu \mathrm{m}$

6. Carbon sorbents ( $\mathrm{B}$ and $\mathrm{C}$ may be different for each configuration)
A) FGD Activated Carbon
B) Sorbent B (small particle size - TBD based on laboratory results)
C) Sorbent C (TBD based on laboratory results)

7. Flyash (TBD based on laboratory results)

High LOI due to low NOx burners

High LOI due to coal characteristics

Eastern flyash

Midwestern Flyash 
A summary of the testing is shown below and detailed on pages 3 through 7. Sorbent A has been identified as FGD carbon. Sorbents B, C, and D may be different for different configurations and will be determined based on results from laboratory testing on other DOE and EPRI programs.

1. Electrostatic Precipitator

1.1 Baseline

1.2 Sorbent A (FGD)

1.3 Sorbent B

1.4 Sorbent $\mathrm{C}$

Vary temperature, residence time and

1.5 ESP Additive

Hg concentration.

2. Pulse-Jet (upstream of reverse-gas baghouse)

2.1 Baseline

2.2 Sorbent A (FGD)

2.3 Sorbent B

2.4 Sorbent $\mathrm{C}$

Vary temperature, and Hg concentration.

Pulse-Jet (downstream of reyerse-gas baghouse with sodium injection for $\mathrm{SO}_{2}$ control)

2.5 Baseline

2.6 Sorbent $D$

3. Toxicon

3.1 Baseline

3.2 Sorbent $\mathrm{D}$

Vary temperature, sorbent

injection, and $\mathrm{Hg}$ concentration.

4. Reverse-Gas Configuration (upstream of existing reverse-gas baghouse)

4.1 Baseline

4.2 Sorbent A (F GD)

4.3 Sorbent B

4.4 Sorbent $C$

Vary temperature, and

Hg concentration.

Reverse-Gas (downstream offeverse-gas baghouse with sodium injection for $\mathrm{SO}_{2}$ control)

4.5 Baseline

4.6 Sorbent D

5. Alternative Ash Tests

5.1 High LOI ash as sorbent

5.2 Midwestern and Eastern flyash evaluations

5.3 Water Spray 
1. Electrostatic Precipitator

\begin{tabular}{|l|c|c|c|c|}
\hline \multicolumn{1}{|c|}{ Test D } & Hg Sorbent & Hg Concentration & Temperature & Res. Time \\
\hline 1.1 Baseline & None & Baseline & $225-275^{\circ} \mathrm{F}$ & 1 sec. \\
\hline \hline $1.2 \mathrm{a}$ Sorbent A & FGD & Baseline & $225-275^{\circ} \mathrm{F}$ & 1 sec. \\
\hline $1.2 \mathrm{~b}$ & FGD & Doped & $225-275^{\circ} \mathrm{F}$ & 1 sec. \\
\hline $1.2 \mathrm{c}$ & FGD & Baseline & $225-275^{\circ} \mathrm{F}$ & B \\
\hline $1.2 \mathrm{~d}$ & FGD & Baseline & $300-325^{\circ} \mathrm{F}$ & 1 sec. \\
\hline $1.2 \mathrm{e}$ & FGD & Baseline & $190-210^{\circ} \mathrm{F}$ & 1 sec. \\
\hline \hline $1.3 \mathrm{a}$ Sorbent B & B & Baseline & $225-275^{\circ} \mathrm{F}$ & $1 \mathrm{sec}$. \\
\hline $1.3 \mathrm{~b}$ & B & Doped & $225-275^{\circ} \mathrm{F}$ & $1 \mathrm{sec}$. \\
\hline $1.3 \mathrm{c}$ & B & Baseline & $225-275^{\circ} \mathrm{F}$ & B \\
\hline $1.3 \mathrm{~d}$ & B & Baseline & $300-325^{\circ} \mathrm{F}$ & $1 \mathrm{sec}$. \\
\hline \hline $1.4 \mathrm{a}$ Sorbent C & C & Baseline & $225-275^{\circ} \mathrm{F}$ & $1 \mathrm{sec}$. \\
\hline $1.4 \mathrm{~b}$ & C & Doped & $225-275^{\circ} \mathrm{F}$ & $1 \mathrm{sec}$. \\
\hline $1.4 \mathrm{c}$ & C & Baseline & $225-275^{\circ} \mathrm{F}$ & B \\
\hline $1.4 \mathrm{~d}$ & B & Baseline & $300-325^{\circ} \mathrm{F}$ & $1 \mathrm{sec}$. \\
\hline \hline $1.5 \mathrm{a}$ ESP Additive & FGD & Baseline & $225-275^{\circ} \mathrm{F}$ & $1 \mathrm{sec}$. \\
\hline $1.5 \mathrm{~b}$ & B or C & Baseline & $225-275^{\circ} \mathrm{F}$ & $1 \mathrm{sec}$. \\
\hline $1.5 \mathrm{c}$ & Baseline & $300-325^{\circ} \mathrm{F}$ & $1 \mathrm{sec}$. \\
\hline
\end{tabular}


2. Pulse-Jet Configuration: Inlet upstream of Comanche R-G baghouse

\begin{tabular}{|c|c|c|c|}
\hline Test ID & Hg Sorbent & Hg Concentration & Temperature \\
\hline 2.1 Baseline & None & Baseline & $225-275^{\circ} \mathrm{F}$ \\
\hline 2.2a Sorbent $\mathrm{A}$ & FGD & Baseline & $225-275^{\circ} \mathrm{F}$ \\
\hline $2.2 b$ & $\overline{\text { FGD }}$ & Doped & $225-275^{\circ} \mathrm{F}$ \\
\hline $2.2 \mathrm{c}$ & FGD & Baseline & $300-325^{\circ} \mathrm{F}$ \\
\hline $2.2 \mathrm{~d}$ & FGD & Baseline & $190-210^{\circ} \mathrm{F}$ \\
\hline 2.3a Sorbent B & $\overline{\mathrm{B}}$ & Baseline & $225-275^{\circ} \mathrm{F}$ \\
\hline $2.3 b$ & $\overline{\mathrm{B}}$ & Doped & $225-275^{\circ} \mathrm{F}$ \\
\hline $2.3 \mathrm{c}$ & $\overline{\mathrm{B}}$ & Baseline & $300-325^{\circ} \mathrm{F}$ \\
\hline $2.4 \mathrm{a}$ Sorbent C & $\overline{\mathrm{C}}$ & Baseline & $225-275^{\circ} \mathrm{F}$ \\
\hline $2.4 b$ & $\bar{C}$ & Doped & $225-275^{\circ} \mathrm{F}$ \\
\hline $2.4 c$ & $\bar{C}$ & Baseline & $300-325^{\circ} \mathrm{F}$ \\
\hline
\end{tabular}

2.5 - 2.6 Pulse-Jet Configuration with Sodium Injection: Inlet downstream of R-G baghouse

\begin{tabular}{|l|c|c|c|}
\hline \multicolumn{1}{|c|}{ Test ID } & Hg Sorbent & Hg Concentration & Temperature \\
\hline 2.5 & None & Baseline & $225-275^{\circ} \mathrm{F}$ \\
\hline $2.6 \mathrm{a}$ & $\mathrm{D}^{*}$ & Baseline & $225-275^{\circ} \mathrm{F}$ \\
\hline $2.6 \mathrm{~b}$ & $\mathrm{D}^{*}$ & Doped & $225-275^{\circ} \mathrm{F}$ \\
\hline $2.6 \mathrm{c}$ & $\mathrm{D}^{*}$ & Baseline & $300-325^{\circ} \mathrm{F}$ \\
\hline
\end{tabular}

* Sorbent D may be A, B, C or alternate sorbent chosen for sodium testing 


\section{Toxicon}

\begin{tabular}{|l|c|c|c|}
\hline \multicolumn{1}{|c|}{ Test ID } & Hg Sorbent & Temperature & Residence Time \\
\hline 3.1 Baseline & Baseline & $225-275^{\circ} \mathrm{F}$ & $1 \mathrm{Sec}$ \\
\hline $3.2 \mathrm{a}$ & $\mathrm{D}^{*}$ & $225-275^{\circ} \mathrm{F}$ & $1 \mathrm{Sec}$. \\
\hline $3.2 \mathrm{~b}$ & $\mathrm{D}^{*}$ int. injection & $225-275^{\circ} \mathrm{F}$ & $1 \mathrm{Sec}$. \\
\hline $3.2 \mathrm{c}$ & $\mathrm{D}^{*}$ & $300-325^{\circ} \mathrm{F}$ & $1 \mathrm{Sec}$. \\
\hline $3.2 \mathrm{~d}$ & $\mathrm{D}^{*}$ & $225-275^{\circ} \mathrm{F}$ & $\mathrm{B}$ \\
\hline
\end{tabular}

* Sorbent identified based on previous tests 
4. Reverse-Gas Configuration: Inlet upstream of Comanche R-G baghouse

\begin{tabular}{|l|c|c|c|}
\hline \multicolumn{1}{|c|}{ Test ID } & Hg Sorbent & Hg Concentration & Temperature \\
\hline 4.1 Baseline & Basleine & Baseline & $225-275^{\circ} \mathrm{F}$ \\
\hline $4.2 \mathrm{a}$ & $\mathrm{A}:$ & Daseline & $225-275^{\circ} \mathrm{F}$ \\
\hline $4.2 \mathrm{~b}$ & $\mathrm{~A}:$ & Baseline & $225-275^{\circ} \mathrm{F}$ \\
\hline $4.2 \mathrm{c}$ & $\mathrm{A}:$ & Baseline & $225-275^{\circ} \mathrm{F}$ \\
\hline $4.3 \mathrm{a}$ & $\mathrm{B}:$ & Doped & $225-275^{\circ} \mathrm{F}$ \\
\hline $4.3 \mathrm{~b}$ & $\mathrm{~B}:$ & Baseline & $300-325^{\circ} \mathrm{F}$ \\
\hline $4.3 \mathrm{c}$ & $\mathrm{B}:$ & Baseline & $225-275^{\circ} \mathrm{F}$ \\
\hline $4.4 \mathrm{a}$ & $\mathrm{C}:$ & Doped & $225-275^{\circ} \mathrm{F}$ \\
\hline $4.4 \mathrm{~b}$ & $\mathrm{C}:$ & Baseline & $300-325^{\circ} \mathrm{F}$ \\
\hline $4.4 \mathrm{c}$ & $\mathrm{C}:$ & & \\
\hline
\end{tabular}

4.5 - 4.6 Reverse-Gas Configuration with Sodium Injection: Inlet downstream of R-G baghouse

\begin{tabular}{|l|c|c|c|}
\hline \multicolumn{1}{|c|}{ Test ID } & Hg Sorbent & Hg Concentration & Temperature \\
\hline 4.5 & None & Baseline & $225-275^{\circ} \mathrm{F}$ \\
\hline $4.6 \mathrm{a}$ & $\mathrm{D}^{*}$ & Baseline & $225-275^{\circ} \mathrm{F}$ \\
\hline $4.6 \mathrm{~b}$ & $\mathrm{D}^{*}$ & Doped & $225-275^{\circ} \mathrm{F}$ \\
\hline $4.6 \mathrm{c}$ & $\mathrm{D}^{*}$ & Baseline & $300-325^{\circ} \mathrm{F}$ \\
\hline
\end{tabular}

* Sorbent D may be A, B, C or alternate sorbent chosen for sodium testing 
5. No Comanche Ash: Particle Control Device:

\begin{tabular}{|l|c|c|c|}
\hline \multicolumn{1}{|c|}{ Test ID } & Hg Sorbent & Flyash & Temperature \\
\hline $5.1 \mathrm{a}$ & None (ash) & LOI 1: & $225-325^{\circ} \mathrm{F}$ \\
\hline $5.1 \mathrm{~b}$ & None (ash) & LOI 2: & $225-325^{\circ} \mathrm{F}$ \\
\hline $5.2 \mathrm{a}$ & FGD & Midwestern: & $225-275^{\circ} \mathrm{F}$ \\
\hline $5.2 \mathrm{~b}$ & FGD & Eastern: & $300-325^{\circ} \mathrm{F}$ \\
\hline 5.3 Water Spray & FGD & None & $225-275^{\circ} \mathrm{F}$ \\
\hline
\end{tabular}

